\title{
Linking Destinations Through Sustainable Cultural Routes
}

\author{
Giulio Pattanaro*, Filippo Pistocchi**
}

\begin{abstract}
The potential for cultural routes to promote tourism destinations and increase their competitiveness has been more and more recognised at both European and global level.

Planning and developing a cultural route linking together different tourism destinations is a rather difficult and complex process. This analysis will concern the proposal - promoted by a French-based pro-Europe association - to create a European cultural route dedicated to Charlemagne., The main findings are expected to serve, inter alia, as a useful toolbox for those tourism decision-makers who are directly involved in the design and development of cultural routes.
\end{abstract}

Keywords: European Cultural Routes; Tourism Planning and Development; Sustainability; Destination Competitiveness; Destination Management; Global Tourism; Global Markets

\section{An Integrated Tourism Product}

A cultural route can be seen as the combination of three elements: the geographical area where the attractions and places of interest are located; the theme which links together the different components of the route; and the tourism products and services which are provided to visitors in the different destinations involved in the route.

If properly planned and developed, a cultural route can contribute to capitalise on both the tangible and the intangible heritage of one or more geographical areas thanks to tourism. Tourism can therefore become a major source of job opportunities and economic development for the towns, cities and regions a route is comprised of. This also explains why cultural routes have been attracting increasing interest not just at European level - mainly through the Council of Europe's Cultural Routes programme, which will be illustrated in the following section - but also at a global scale. The United Nations World Tourism Organization recently released, for example, a report on cultural routes and itineraries collecting best practices from all continents (UNWTO, 2015).

\footnotetext{
*Independent Researcher, (giuliopattanaro@gmail.com)

** Adjunct Professor of Geography, Alma Mater Studiorum University of Bologna, (filippo.pistocchi@unibo.it)
} 
In order to plan and develop a cultural route able to generate benefits for the local economy, a series of elements have to be taken into account. For instance, the theme around which an itinerary is built needs to be able to clearly link up the different destinations while, at the same time, be appealing to external visitors.

This paper will examine the key components of a cultural route, as well as the main steps of the planning process. A review of the most relevant literature on the subject will be combined with the analysis of the proposal - put forward by a French-based pro-Europe association - to create a European cultural route dedicated to Charlemagne. The main findings of this paper are expected to serve, inter alia, as a useful toolbox for those tourism decision-makers who are directly involved in the design and development of cultural routes both in Europe and elsewhere.

\section{Planning a Sustainable Cultural Route}

As observed by Murray and Graham (1997), the essence of cultural routes “...is that they combine cultural consumption with points of sale and are inextricably linked - as with all heritage tourism - to a continuous re-imaging of place and culture that draws inspiration from nostalgia, memory and tradition" (Murray \& Graham, 1997, p. 514). These itineraries have therefore the potential to enhance a region's attractiveness and competitiveness from both a cultural and tourism point of view (OECD, 2009). Moreover, according to Meyer (2004), “...most routes are initiated with one or more of the following objectives in mind:

- to diffuse visitors and disperse income from tourism;

- to bring lesser known attractions and features into the tourism business/product;

- to increase the overall appeal of a destination;

- to increase length of stay and spending by tourists;

- to attract new tourists and to attract repeat visitors; and

- to increase the sustainability of the tourism product." (Meyer, 2004, p. 3).

The last point underlined by Meyer becomes particularly important in the case of cultural tourism and cultural routes, where generally well-informed tourists are searching for an authentic and participatory cultural experience based also on the interaction and exchange with the local population (Majdoub 2010; Richards \& Wilson, 2008; Rizzo, Rizzo, \& Trono, 2013).

Nonetheless, planning and developing a cultural route able to meet the abovementioned objectives is a rather difficult and complex process.

Some interesting suggestions are provided by López Fernández (2006), who invites the planners and actors involved in the development of a cultural route to carefully take into account the elements which are reported in Table 1. 
Table 1: Elements to Take into Account in the Development of a Cultural Route

\begin{tabular}{|c|c|}
\hline Indicator & Specific measuring instruments \\
\hline Justification & $\begin{array}{l}\text { The creation of a particular route needs to } \\
\text { be supported by a valid raison d'être (e.g., } \\
\text { preservation of cultural heritage and/or the } \\
\text { economic development of the area) }\end{array}$ \\
\hline Main goal & $\begin{array}{l}\text { Decision-makers need to have a clear } \\
\text { vision of the main goal that they want to } \\
\text { attain (e.g., enhancing the tourism } \\
\text { attractiveness of a particular area) and this } \\
\text { goal must be realistic and achievable }\end{array}$ \\
\hline Objectives or sub-goals & $\begin{array}{l}\text { A series of clear and measurable objectives } \\
\text { need to be identified }\end{array}$ \\
\hline $\begin{array}{l}\text { Inventory of the assets and information } \\
\text { available }\end{array}$ & $\begin{array}{l}\text { Planners need to list the assets (e.g., } \\
\text { monuments, museums, tourism facilities, } \\
\text { etc.) they can count on and gather all the } \\
\text { information which is available }\end{array}$ \\
\hline Market potential & $\begin{array}{l}\text { Some in-depth market research is needed to } \\
\text { understand i) the attractiveness of the } \\
\text { theme around which the itinerary is built ii) } \\
\text { what typology of tourists can be attracted } \\
\text { by the cultural route which is to be } \\
\text { launched iii) the potential impact of the } \\
\text { route on the local economy of the } \\
\text { destinations which are involved. }\end{array}$ \\
\hline $\begin{array}{l}\text { Design and commercialisation of the } \\
\text { itinerary }\end{array}$ & $\begin{array}{l}\text { - verification of the accessibility of all the } \\
\text { destinations included in the route } \\
\text { - analysis and integration of the different } \\
\text { assets and resources which are available } \\
\text { - accessibility of the most relevant } \\
\text { documentation } \\
\text { - definition of the number of suggested } \\
\text { stops and estimation of the time needed } \\
\text { for the tourist to go through all these } \\
\text { stops } \\
\text { - indication of an opening date for the } \\
\text { itinerary } \\
\text { - identification of the funding mechanisms } \\
\text { able to guarantee the long-term } \\
\text { sustainability of the route } \\
\text { - design of a logo to be reproduced in all } \\
\text { stops } \\
\text { - definition of a joint strategy to promote } \\
\text { and commercialise the itinerary } \\
\text { - identification of some indicators to } \\
\text { monitor and evaluate the initiative }\end{array}$ \\
\hline
\end{tabular}

Source: adapted from López Fernández (2006) 
To integrate and complement the suggestions provided by López Fernández, it is worth focusing on three elements whose relevance for the planning of cultural routes is particularly stressed by literature:

- collaboration among actors;

- accessibility;

- monitoring.

Although tourism destinations tend to be perceived and consumed by tourists as "a brand comprising of a collection of suppliers and services" (Buhalis, 2000, p. 99), in reality, many are the actors (e.g., local authorities, private investors and local community), groups and networks of actors who are involved in the tourism development of an area and who have a role to play in the creation of both the tourist product and experience (Bramwell \& Lane, 2000; Buhalis, 2000; Capriello \& Fraquelli, 2008; Fyall \& Garrod, 2005; Pforr, 2006; Shih, 2006). The number of actors further multiplies in the case of tourism routes, where different destinations are to be working together. This is why it is of paramount importance that all the players involved in the planning and development of a particular itinerary actively cooperate and collaborate, by combining resources and efforts and exchanging information and expertise (Beltramo, 2013; Briedenhann \& Wickens, 2004; Majdoub, 2010; Mariotti, 2012). Furthermore, the active involvement of one of these players, the local community, may contribute to enhancing the overall sustainability of the initiative and may lead to the provision of a more authentic tourism product (Bahaire \& Elliott-White, 1999; Hall, 1994).

The literature on partnerships and networks governance (in particular, see Augustyn \& Knowles, 2000; Bramwell \& Lane, 2000; Bramwell \& Sharman, 1999; Jamal \& Getz, 1995; Pforr, 2006; Provan \& Kenis, 2008; Shih, 2006; UNWTO, 2003) provides some suggestions on how to structure and run an effective cooperation and collaboration process among local tourism players. Inter alia, the following elements appear to be particularly relevant: the need for all local actors and networks to recognise their strong interdependence; a joint formulation of the goals and objectives to be achieved through the collaborative process; the need to identify and respond to actors and networks' demands; the presence of a strong political will and support; and the set-up of a monitoring and feedback mechanism. In this context, the public sector is called to play a key role in encouraging and facilitating cooperation among competing local companies, the so-called coopetition (Mariani \& Kylänen, 2014).

The establishment of an effective cooperation and collaboration process among the different actors of a cultural route frequently becomes a prerequisite for the route to receive some financial support from public authorities. This is the case, for example, of a recent call for proposals published by the European Commission (EC, 2014) with the aim of encouraging the development of tourism products on a transnational and European scale. In the text of the call, it is clearly stated that the successful proposal should target the "...facilitation and stimulation of publicprivate partnerships and involvement of tourism enterprises, in particular micro and small, in the supply chain of transnational thematic tourism products as well as into regional development and tourism promotional strategies" (EC, 2014, p. 6).

Cooperation and collaboration among the different actors involved in a cultural route is also key to ensure the overall accessibility of an itinerary. As Díez Santo (2011) observes, the presence of monuments, museums and other elements of 
cultural interest is not enough for the development of an itinerary. Tourism services and facilities (hotels, restaurants, bike rental companies, etc.) need to be accessible to visitors in all the different destinations, and the staff employed in these tourism services need to be properly trained. The accessibility of an itinerary is also related to transportation and information. The different sites and points of interest must be easily reachable by as many means of transport as possible, and full accessibility needs to be guaranteed within the different destinations as well. Information on how to reach each single destination - but also on the attractions and tourism facilities which are present within each single destination - must be easily accessible. In this context, a useful tool in support of cultural route planners may be represented by online platforms. These platforms - which can be consulted by tourists via smart phones while they are travelling from a place to another - offer the opportunity to aggregate information from different sources in order to provide an almost complete overview of a route and its stops, including feedback from previous visitors and the possibility for the tourist to get some personalised services and assistance (Miguéns, Baggio, \& Costa, 2008; Buhalis \& Law, 2008; Pourabedin, Hosseini, \& Nourizadeh, 2011).

Accessibility may become part of the elements which are monitored regularly by the planners of an itinerary. To further explore the issue of monitoring in the context of cultural routes, it is here worth mentioning some useful indicators developed by the Council of Europe and the European Commission. In 1987, the Council of Europe - an international organisation which is based in Strasbourg (France) and promotes human rights and cultural diversity (CoE, 2016) - launched the Cultural Routes programme with the aim to "...contribute to the promotion of European identity and citizenship through knowledge and awareness of Europe's common heritage, and the development of cultural links and dialogue within Europe as well as with other countries and regions" (CoE, 2013, art. 1). Since then, 33 cultural itineraries have gained the certification of Council of Europe Cultural Route (EICR, 2016), and the list includes well-known routes like the Santiago de Compostela Pilgrim Route (certified in 1987), the Hansa (certified in 1991) or the Via Francigena (certified in 1994). Since 1998, an executive agency of the Council of Europe - the European Institute of Cultural Routes - is responsible for implementing the Cultural Routes programme (EICR, 2016).

In the context of this programme, the Council of Europe and the European Commission jointly released in 2011 a study on the impact of Coucil of Europe Cultural Routes on the innovation and competitiveness of small and medium-sized enterprises (CoE \& EC, 2011). As part of the study, a series of key indicators to assess the economic impact and the sustainability, from a socio-economic and environmental perspective, of a cultural route was developed. In relation to the economic impact of a cultural route, the study invites to regularly monitor the following indicators: number of visitors and overnight stays; visitor spend; number of start-ups and growth rate of existing businesses; number of organisations provided with training and consulting (and related number of hours); number of existing and newly-created jobs; and number of web and social media hits.

With regard to the social and environmental sustainability of a cultural route, the Council of Europe and the European Commission directly mention a list of sustainable development indicators elaborated by Ceron and Dubois (2003). The list is reported in Table 2. 
Table 2: Indicators of Socio-Economic and Environmental Sustainability for Cultural Routes

\begin{tabular}{|c|c|}
\hline Indicator & Specific measuring instruments \\
\hline Site protection & $\begin{array}{l}\text { Category of site protection according to the } \\
\text { index developed by the International Union } \\
\text { for Conservation of Nature (IUCN) }\end{array}$ \\
\hline Pressure & Frequency of tourists (visitor numbers) \\
\hline Intensity of use & $\begin{array}{l}\begin{array}{l}\text { Intensity of use in peak period } \\
\text { (people/area) }\end{array} \\
\end{array}$ \\
\hline Social impact & $\begin{array}{l}\text { Ration tourists/inhabitants (average and } \\
\text { peak period) }\end{array}$ \\
\hline Development control & $\begin{array}{l}\text { Existence of a procedure to study the } \\
\text { environment or of true controls as regards } \\
\text { planning and density of use }\end{array}$ \\
\hline Waste management & Percentage of waste water treated \\
\hline Planning process & $\begin{array}{l}\text { Existence of a systematic plan for the } \\
\text { area/of the tourist destination }\end{array}$ \\
\hline Fragile ecosystems & $\begin{array}{l}\text { Monitoring of (rare or threatened) species } \\
\text { and habitats }\end{array}$ \\
\hline Consumer satisfaction & $\begin{array}{l}\text { Degree of satisfaction of the visitors } \\
\text { (according to a questionnaire) }\end{array}$ \\
\hline $\begin{array}{l}\text { Satisfaction of inhabitants } \\
\text { Quality of life }\end{array}$ & $\begin{array}{l}\text { Degree of satisfaction of the inhabitants } \\
\text { (according to a questionnaire), barometer } \\
\text { among the locals }\end{array}$ \\
\hline $\begin{array}{l}\text { Contribution of tourism to the local } \\
\text { economy }\end{array}$ & $\begin{array}{l}\text { Proportion of the global economic activity } \\
\text { due solely to tourism, actual revenues from } \\
\text { the added value of tourism }\end{array}$ \\
\hline Carrying capacity & $\begin{array}{l}\text { Composite measuring instrument warning } \\
\text { about the state of key factors influencing } \\
\text { the capacity of the site to handle various } \\
\text { levels of tourism }\end{array}$ \\
\hline Site disturbance & $\begin{array}{l}\text { Composite measuring instrument of impact } \\
\text { levels on the site }\end{array}$ \\
\hline Interest & $\begin{array}{l}\text { Composite measuring instrument of } \\
\text { characteristics of the site which make it } \\
\text { attractive for tourism and which can change } \\
\text { over time }\end{array}$ \\
\hline Customer satisfaction & Survey score \\
\hline
\end{tabular}

Source: adapted from CoE and EC (2011), p. 114

\section{A Cultural Route in the Making}

In order to acquire a better understanding of the planning and development of cultural routes, the indications provided by literature were combined with the results of a case-study analysis. The adoption of a case-study approach is actually considered to allow for an in-depth investigation of the issues at stake (Eisenhardt, 1989; Yin, 2003). 
As case study, the authors decided to analyse the proposal - which has been put forward since 2011 by a French-based pro-Europe association - to create a European cultural route dedicated to Charlemagne. The itinerary is named Via Charlemagne and most of its stops concentrate in the area comprised between Paris (France), Aachen (Germany) and the Grand Duchy of Luxembourg.

This particular case study was selected for a twofold reason: first, the large amount of information made available to the public by the proposers; second, the possibility for one of the authors - based in Brussels (Belgium) at the time of the investigation - to easily visit some of the destinations which are part of the proposed itinerary.

In terms of data collection, information from different sources (the website dedicated to the initiative, other local tourism websites, local press, etc.) was integrated with the data collected by one of the authors in his visits to some of the destinations which have been included in the proposed cultural route. More in detail, five one-day field trips were organised, in the period going from 11 October 2014 to 23 November 2014, in the following cities: Aachen (Germany); Liège (Belgium); Luxembourg City (Luxembourg), Namur (Belgium) and Reims (France). The author pretended to be an ordinary tourist and asked the staff of the local tourism office for some information concerning the Charlemagne heritage in the area.

The final purpose was to understand what each of these destinations has actually to offer to the visitors who are willing to go through the Via Charlemagne. Furthermore, the authors wanted to observe whether the staff providing information to tourists was aware of the proposal.

An effort was made to at least partially overcome the limitations of the qualitative method used: a non-academic language was used and comments or attitudes that could have disclosed the real purpose of the visit were avoided.

The idea to create a European cultural route dedicated to Charlemagne, the socalled Via Charlemagne, has been proposed since 2011 by the France-based association Mouvement Européen Marne, which is part of a network of pro-Europe organisations called European Movement International (EMI, 2016).

As it is clearly stated in the webpage of the initiative, the proposed route aims at making people rediscover the roots of the European culture, by following the footsteps of an emperor, Charlemagne, who is considered among the founders of today's Europe (MEM, 2016).

The itinerary extends from Barcelona (Spain) to Riga (Latvia) and most of its stops are concentrated in the transnational region comprised between Paris (France), Aachen (Germany) and the Grand Duchy of Luxembourg (see maps in MEM, 2016).

The Via Charlemagne puts together towns and cities where the emperor spent part of its life (e.g., Aachen) with other urban centres where the Carolingian heritage has always been very present (e.g., Riga with its statue of Roland, Charlemagne's nephew and symbol of freedom in many Hanseatic cities).

The emperor's seal has been selected as the official logo of the Via Charlemagne project.

Once the route is further developed, the proposers of the initiative would like to apply for the Council of Europe Cultural Route certification (MEM, 2016). At the time of writing, no official application has been submitted yet (EICR, 2016). 
Based on the information collected via both primary and secondary research, and taking into account the suggestions provided by literature, the authors have identified a set of factors which may contribute to the successful development of the Via Charlemagne project. At the same time, a series of shortcomings and elements to be improved have been pointed out.

The first factor which may help to ensure the successful development of the initiative is the theme chosen for this particular cultural route. Charlemagne has always been considered as a key figure in European history and back in the Middle Ages the emperor was even raised to sainthood (Depreux, 2014; MVH, 2014; Rogeau, 2014). Also today, news related to Charlemagne and his heritage are reported quite frequently in the press (e.g., see Alié, 2014; Crémers, 2013; Gihousse, 2014; Jacquemin, 2012; RA, 2014) and a former Carolingian capital city such as Aachen has been effectively building its image and tourism brand around the emperor (Aachen, 2016). Therefore, the Via Charlemagne appears to have some good market potential and attractiveness. Furthermore, the importance of Charlemagne for Europe's history may also increase the chances for this itinerary to gain the Council of Europe Cultural Route certification, as it is in the plans of the proposers.

Based on the information provided in the website of the initiative (MEM, 2016), it also appears that both the Mouvement Européen Marne and the other players who have already decided to join the project have a clear common goal, which is the promotion of Europe's common culture combined with the enhancement of the tourism attractiveness of the regions the itinerary is comprised of.

The Via Charlemagne can also count on a good and diversified tourism offer. Next to the Carolingian heritage, for example, destinations like Reims or Liège are already present in the tourism marketplace with a well-reputed tradition of wine\&food (e.g., the champagne wine in Reims) and a series of events (e.g., the Liège-Bastogne-Liège cycle race) able to attract visitors from outside the regional area. This diversified offer makes it possible for these destinations to enrich the overall tourist experience, to attract different typologies of visitors and bring more benefits to the local economy. Tourists who are already visiting one of these destinations for a different reason (e.g., wine\&food experience) may be encouraged to discover the Via Charlemagne's sites and attractions.

The efforts put on the communication of the initiative by its proposers may also contribute to the successful development of this cultural route. Even if some information and some translations are still missing, a website (MEM, 2016) that serves as a sort of inventory for the project is currently in place; furthermore, the proposal has already acquired some good coverage in the local press of the regions interested by the initiative (e.g., see Bechet, 2013; Crémers, 2013; Gihousse, 2014; RUA, 2014).

Part of this good coverage is probably linked to the high-level political support the Via Charlemagne can count on. As it is highlighted in the website dedicated to the project (MEM, 2016), the initiative has already been supported by the President of the European Parliament, Martin Schultz, and by the Representation of the European Commission in France. In this regard, it certainly helps to have a former Member of the European Parliament, Jean-Marie Beaupuy, as President of the Mouvement Européen Marne. 
At the same time, it is the authors' opinion that further efforts should be made by the proposers to illustrate the Via Charlemagne initiative to the staff in charge of providing information to tourists in the different destinations of the itinerary. The direct experience of one of the authors showed that only in two out of five destinations the staff of the local tourism offices was aware of an ongoing project aiming at promoting the Carolingian heritage. With the exception of Aachen, primary research also pointed out the limited knowledge of local tourism staff with regard to the places and monuments related to the figure of Charlemagne. This was particularly true in destinations like Reims, where tourism is linked mainly to other typologies of products (e.g., wine\&food and Gothic art). Furthermore, despite its actual presence and relevance, almost no information could be collected in relation to Charlemagne-related heritage located just outside the urban areas which were visited. For example, during the visit to Liege's tourism office, it was very difficult to get some information with regard to an exhibition dedicated to Charlemagne which was taking place in the near-by town of Herstal (Herstal, 2015; MVH, 2014).

Part of this lack of information is most probably due to a low level of cooperation and collaboration among the different destinations the proposed route is comprised of. An enhanced collaboration would help to develop a more unified image of the itinerary and the tourist would have the feeling that all stops are part of a common and integrated project. Furthermore, the marketing strategies of the different local tourism operators would benefit from the exchange of data and information on the characteristics and demands of visitors. As a sign of this increased cooperation and collaboration, some support material providing an overview of the Via Charlemagne should be made available in every stop and local tourism operators should be more active in promoting their own Carolingian heritage but also that of the other destinations included in the cultural route.

Further cooperation - with the set-up, for instance, of ad-hoc roundtables with participants from all the destinations - could also help to improve the accessibility of the route by public transportation. As experienced by the authors themselves at the moment of planning the five field trips, due to the lack of direct connections, it is almost impossible for a tourist who does not travel by car to go through the itinerary in the direction suggested by the proposers (see maps in MEM, 2016). For instance, no direct international train connections between Reims and Belgium exist, and tourists have to go to Paris to reach Namur, Liège or another Belgian site (SNCB, 2016; SNCF, 2016). The suggested multi-actor and multi-destination roundtables could be shaped based on the experience of the already established ones, which have been built around the following themes: tourism, culture, training and education (MEM, 2016).

The proposers of the Via Charlemagne should also consider the possibility to directly cooperate with an already existing itinerary which gained the Council of Europe Cultural Route certification in 2007: the Via Carolingia. This cultural route - which was promoted by Italy's Ministry for Cultural Heritage and Tourism crosses Germany, Belgium, France, Switzerland and Italy and is dedicated to a specific episode of Charlemagne's life: his trip from Aachen to Rome in the year 800 to be crowned Emperor of the Romans by Pope Leo III (EICR, 2016). Both primary and secondary research shows that there is no interaction between the proposers of the two routes. At the same time, no particular political reason appears to justify this. It is the authors' belief that the establishment of contacts and 
relations between the two itineraries would be of benefit for both routes: the Via Charlemagne could benefit from the experience already acquired by the tourism operators of the Via Carolingia and the latter could provide its visitors with the possibility to discover other cities, towns and attractions linked to the Carolingian heritage.

The experience which has been already acquired by the proposers of the Via Carolingia could also help the Mouvement Européen Marne elaborate and implement a series of indicators to monitor both the economic and sustainability impact of the proposed itinerary. As it can be seen in the website of the initiative (MEM, 2016), the proposers of this new cultural route are frequently mentioning the positive impact of the expected flows of visitors for the economic development of the different stops. Nonetheless, no specific indicator to monitor this expected economic impact seems to have been developed so far. The same is true for socioenvironmental issues: it is not clear how the proposers are going to guarantee the sustainability of the route in the long term, avoiding negative impacts on the environment and preserving and improving the quality of life of the local population. Last but not least, customer satisfaction - which, as it was reported (see CoE \& EC, 2011), can be included within the indicators of sustainability - is not measured either. Here as well, the set-up of an ad-hoc multi-actor and multidestination roundtable dedicated to sustainability issues could be of help.

Further action should also be taken in relation to funding. Based on the analysis carried out by the authors, it appears that, at the moment of writing, no discussion among the different destinations which are part of the Via Charlemagne has been launched in relation to the way this cultural route will sustain itself. The experience of other Council of Europe Cultural Routes can provide some suggestions in this regard. For instance, every city involved in the Hansa itinerary has agreed to contribute with an annual fee for the development of the website dedicated to the initiative; at the same time, each city is responsible for funding its own activities, with the support, if possible, of private sponsors (CoE \& EC, 2011; Die Hanse, 2015). As it was discussed in the literature review session of this paper, the possibility and the prerequisites to get some funding at European level should also be explored by the proposers.

Perhaps, this delay in the elaboration of indicators and funding mechanism is due to the early stage of development of the Via Charlemagne project. If this is the case, the authors would strongly recommend taking all the necessary steps to tackle these issues as soon as possible. An agreement on how to fund at least the joint activities, together with the identification of common and measurable indicators for socio-environmental and economic impact, is expected to reinforce the commitment of the stakeholders and destinations involved in the initiative and to increase the chance of obtaining the Council of Europe Cultural Route certification.

\section{A Toolbox for Tourism Decision-Makers}

This paper aimed at identifying the elements and factors which facilitate the planning and development of sustainable cultural routes, linking together different tourism destinations. Based on the suggestions coming from literature and the results of the analysis of the Via Charlemagne initiative, planners and actors 
involved in the development of a cultural route are invited to pay particular attention to the following nine elements:

1. theme: the cultural itinerary needs to be centered around an appealing theme, able to attract visitors and tourists;

2. goal: the players from the different destinations involved in the development of a cultural route have to agree on the main objectives that they want to reach through their initiative;

3. destinations: to reach out to different typologies of visitors, it is recommended to develop a cultural route where tourism offer is as diversified as possible (e.g., well-reputed wine\&food destinations to be combined with famous cultural heritage sites). The possibility to cooperate and/or integrate with other already existing itineraries should also be explored;

4. inventory: the assets and resources of the different destinations and attractions involved in the itinerary must be carefully examined and catalogued;

5. accessibility: planners and developers need to guarantee the full accessibility (easy access to information, easy access to tourism facilities and services, easy access by public transportantion) of all the destinations which are part of route;

6. communication: the cultural route must be effectively communicated and promoted (development of a common logo, creation of an online platform, etc.);

7. political support: getting the support of key political figures may help to give visibility to a cultural itinerary and to attract new actors (e.g., new municipalities);

8. funding: the cultural route needs to be able of sustain itself, possibly with the support of some external funding sources (e.g., European funds, private sponsors, etc.);

9. monitoring: it is important that all the aspects of the route - the economic benefits it has been generating, but also its socio-environmental sustainability and the satisfaction of visitors - are constantly assessed, and monitoring schemes developed in the context of other cultural routes can be applied.

These elements imply the presence of a preconditional factor: the existence of an effective and continous cooperation and collaboration among the different actors and the destinations involved in the planning and development of a cultural route. As it was clearly stated by literature, cooperation and collaboration among actors is key to provide a unique and coherent image of the itinerary. Furthermore, the exchange of information and know-how helps local operators to better meet tourist demands and expectations and often constitutes a prerequisite for the route to receive some financial support from external sources. In addition to this, the involvement of all the local actors (local residents included) may contribute to developing a more sustainable tourism product.

The elements and suggestions which have been illustrated in the previous paragraphs are expected to work as a useful toolbox for those tourism decisionmakers who are directly involved in the design and development of cultural routes in Europe and elsewhere.

At the same time, the authors are aware of the limitations of their work: the casestudy analysis concerned one cultural route proposal only. Furthermore, primary research was limited to five one-day field-trips in which one of the authors 
pretended to be a visitor asking for some information at the local tourism offices. The visit to a larger number of destinations and the organisation of interviews and focus groups with local tourism operators and authorities would have certainly provided a more in-depth understanding of the state-of-the-art of the initiative and the issues involved.

It is therefore here suggested to keep on examing and comparing the Via Charlemagne and other similar projects. The authors strongly believe that a continous and thorough analysis of this type of initiatives will help to ensure the economic and sustainable development of the areas and destinations interested by a particular itinerary, which is the main reason why cultural routes are planned and designed.

\section{Bibliography}

Aachen. (2016). Route Charlemagne Aachen. Retrieved from http://www.route-charlemagne.eu

Alié, B. (2014, January 28). Herstal célèbre le 1200e anniversaire de la mort de Charlemagne. Radio Télévision Belge Francophone. Retrieved from http://www.rtbf.be

Augustyn, M. M., \& Knowles, T. (2000). Performance of tourism partnerships: a focus on York. Tourism Management, 21, 341-351.

http://dx.doi.org/10.1016/S0261-5177(99)00068-0

Bahaire, T., \& Elliott-White, M. (1999). Community Participation in Tourism Planning and Development in the Historic City of York, England. Current Issues in Tourism, 2(2-3), 243-276. http://dx.doi.org/10.1080/13683509908667854

Bechet, M. (2013, September 19). Étape Charlemagne. La Dernière Heure. Retrieved from http://www.dhnet.be

Beltramo, S. (2013) Cultural Routes and Networks of Knowledge: the identity and promotion of cultural heritage - The case study of Piedmont. AlmaTourism, 4(7), 13-28. http://dx.doi.org/10.6092/issn.2036-5195/3908

Bramwell, B., \& Lane, B. (2000). Collaboration and Partnerships in Tourism Planning. In in B. Bramwell, \& B. Lane (Eds.), Tourism Collaboration and Partnerships. Politics, Practice and Sustainability (pp. 1-19). Clevedon: Channel View Publications.

Bramwell, B., \& Sharman, A. (1999). Collaboration in local tourism policy-making. Annals of Tourism Research, 26(2), 392-415.

http://dx.doi.org/10.1016/S0160-7383(98)00105-4

Briedenhann, J., \& Wickens, E. (2004). Tourism routes as a tool for the economic development of rural areas-vibrant hope or impossible dream? Tourism Management, 25(1), 71-79. http://dx.doi.org/10.1016/S0261-5177(03)00063-3

Buhalis, D. (2000). Marketing the competitive destination of the future. Tourism Management, 21(1), 97-116.

http://dx.doi.org/10.1016/S0261-5177(99)00095-3

Buhalis, D., \& Law, R. (2008). Progress in information technology and tourism management: 20 years on and 10 years after the Internet - The state of eTourism research. Tourism Management, 29(4), 609-623.

http://dx.doi.org/10.1016/j.tourman.2008.01.005

Capriello, A., \& Fraquelli, G. (2008) Market-Driven Management in Community Events. Symphonya. Emerging Issues in Management (symphonya.unimib.it), 2, 50-65. http://dx.doi.org/10.4468/2008.2.05capriello.fraquelli

Ceron, J.-P., \& Dubois, G. (2003). Tourism and sustainable development indicators: the gap between theoretical demands and practical achievements. Current Issues in Tourism, 6(1), 54-75. http://dx.doi.org/10.1080/13683500308667944 
Council of Europe (CoE). (2016). Council of Europe. Retrieved from http://www.coe.int

Council of Europe (CoE). (2013). Resolution CM/Res(2013)66 confirming the establishment of the Enlarged Partial Agreement on Cultural Routes (EPA). Retrieved from https://wcd.coe.int

Council of Europe, \& European Commission (CoE \& EC). (2011). Impact of European Cultural Routes on SMEs' innovation and competitiveness - provisional edition. Retrieved from http://www.coe.int

Crémers, J. (2013, September 17). Herstal va commémorer l'anniversaire de la mort de Charlemagne. Radio Télévision Belge Francophone. Retrieved from http://www.rtbf.be

Depreux, P. (2014). La légende de Charlemagne Le Conquérant. Archéothéma, 34, 19.

Die Hanse. (2015). Die Hanse. Retrieved from http://www.hanse.org

Díez Santo, D. (2011). La planificación estratégica en espacios turísticos de interior: Claves para el diseño y formulación de estrategias competitivas. Investigaciones Turísticas, 1, 69-92. http://dx.doi.org/10.14198/INTURI2011.1.05

Eisenhardt, K. M. (1989). Building theories from case study research. Academy of Management Review, 14(4), 532-550. http://dx.doi.org/10.2307/258557

European Commission (EC). (2014). COS-WP2014-3-15-03 - Diversifying the EU Tourism Offer and Products - Sustainable Transnational Tourism Products 2014. Retrieved from http://ec.europa.eu

European Institute of Cultural Routes (EICR). (2016). European Institute of Cultural Routes. Retrieved from http://www.culture-routes.net

European Movement International (EMI). (2015). European Movement International. Retrieved from http://europeanmovement.eu

Fyall, A., \& Garrod, B. (2005). Tourism Marketing: A Collaborative Approach. Clevedon: Channel View Publications.

Gihousse, M.-F. (2014, January 27) Ce 28 janvier, douze siècles que Charlemagne est mort. L'avenir. Retrieved from http://www.lavenir.net

Hall, C. M. (1994). Tourism and Politics - Policy, Power and Place. Chichester: Wiley.

Herstal. (2015). Herstal. Retrieved from http://www.herstal.be

Jacquemin, P. (2012, September 11) La statue de Charlemagne est de retour boulevard d'Avroy à Liège. Radio Télévision Belge Francophone. Retrieved from http://www.rtbf.be

Jamal, T. B., \& Getz, D. (1995). Collaboration theory and community tourism planning. Annals of Tourism Research, 22(1), 186-204.

http://dx.doi.org/10.1016/0160-7383(94)00067-3

López Fernández, M. I. (2006). Diseño y programación de itinerarios culturales. PH Boletín del Instituto Andaluz del Patrimonio Histórico, 60, 20-33.

Majdoub, W. (2010). Analyzing cultural routes from a multidimensional perspective. AlmaTourism, 1(2), 29-37.

http://dx.doi.org/10.6092/issn.2036-5195/2029

Mariani, M. M., \& Kylänen, M. (2014). The Relevance of Public-Private Partnerships in Coopetition: Empirical Evidence from the Tourism Sector. International Journal of Business Environment, 6(1), 106-125.

http://dx.doi.org/10.1504/IJBE.2014.058026

Mariotti, A. (2012). Local System, Networks and International Competitiveness: from Cultural Heritage to Cultural Routes. AlmaTourism, 3(5), 81-95. http://dx.doi.org/10.6092/issn.2036$5195 / 3208$

Meyer, D. (2004). Routes and Gateways: Key issues for the development of tourism routes and gateways and their potential for Pro-Poor Tourism. Retrieved from http://www.odi.org

Miguéns, J., Baggio, R., \& Costa, C. (2008). Social media and tourism destinations: TripAdvisor.com case study. Advances in tourism research, 26(28), 1-6. 
Mouvement Européen Marne (MEM). (2016). Route Charlemagne. Retrieved from http://routecharlemagne.wordpress.com

Murray, M., \& Graham, B. (1997). Exploring the dialectics of route-based tourism: the Camino de Santiago. Tourism Management, 18(8), 513-524.

http://dx.doi.org/10.1016/S0261-5177(97)00075-7

Musée de la Ville de Herstal (MVH). (2014). Charlemagne: du royaume franc à l'empire, de Herstal à Aachen. Herstal: Musée de la Ville de Herstal.

Organisation for Economic Co-operation and Development (OECD). (2009). The Impact of Culture on Tourism. Retrieved from http://www.oecd.org

Pforr, C. (2006). Tourism policy in the making: an Australian network study. Annals of Tourism Research, 33(1), 87-108.

http://dx.doi.org/10.1016/j.annals.2005.04.004

Pourabedin, Z., Hosseini, S., \& Nourizadeh, A. (2011). Heritage Tourism Website Evaluation Framework. International Conference on Management (ICM 2011) Proceeding, 625-630.

Provan, K. G., \& Kenis, P. (2008). Modes of network governance: Structure, management, and effectiveness. Journal of Public Administration Research and Theory, 18(2), 229-252. http://dx.doi.org/10.1093/jopart/mum015

Rédaction L'Avenir (RA). (2014, October 8). Un espace consacré à Charlemagne inauguré au musée communal d'Herstal. L'Avenir. Retrieved from http://m.lavenir.net

Rédaction L'Union - L'Ardennais (RUA). (2013, September 7). Étape Charlemagne. La Dernière Heure. Retrieved from http://www.lunion.presse.fr

Richards, G., \& Wilson, J. (2006). Developing creativity in tourist experiences: A solution to the serial reproduction of culture? Tourism Management, 27(6), 1209-1223. http://dx.doi.org/10.1016/j.tourman.2005.06.002

Rizzo, L. S., Rizzo, R. G., \& Trono, A. (2013). Religious Itineraries as the Driving Forces behind Sustainable Local Development in the Veneto? Towards a Proposal for Promoting an Unusual and Often "Subliminal” Form of Heritage: Sanctuaries and Minor Churches. Almatourism, 4(7), 59-89. http://dx.doi.org/10.6092/issn.2036-5195/3909

Rogeau, O. (2014, June 18). Les secrets de Charlemagne dévoilés. Le Vif/L'Express. Retrieved from http://www.levif.be

Shih, H.-Y. (2006). Network characteristics of drive tourism destinations: an application of network analysis in tourism. Tourism Management, 27(5), 1029-1039. http://dx.doi.org/10.1016/j.tourman.2005.08.002

Société Nationale des Chemins de fer Belges (SNCB). (2016). Belgian Rail. Retrieved from http://www.belgianrail.be

Société Nationale des Chemins de fer Français (SNCF). (2016). Voyages SNCF. Retrieved from http://www.voyages-sncf.com

United Nations World Tourism Organization (UNWTO). (2015). Global Report on Cultural Routes and Itineraries. Madrid: UNWTO.

United Nations World Tourism Organization (UNWTO). (2013). Co-operation and Partnerships in Tourism - A Global Perspective. Madrid: UNWTO.

Yin, R. K. (2003). Case study research: Design and methods (3rd ed.). London: Sage. 